\section{天然色顕微鏡写真の実技 (その 2 )}

菅井健治・福士勝成・川津邦雄

国立らい研究所, 病理学研究窒

（所長：小林六造, 研究部長：義汇義雄）

前号のつゔき

\section{IV. 照明方法とその調節}

私共は菌検索の目的で油浸装置を利用する事が多く， 此の為には十分の光量が要求される訳である。又現在の カラーフィルムの多くは相反則不規の為, 低照度で長時 間露光を与えるとカラーバランスが失われて了う。

一方被写体が動体でない限り，一般的に言つて $1 / 25 \sim$ 1 秒間の露光時間で適正露光量となる様なピントグラス 面の照度を得る事が望ましいとされている。之以此の範 囲のシヤッター効率が良く而も速度調節の精度が高いか らでもある。

中心透過照明と呼ぶ一般の照明法注集光レンズ（コレ クター）を使う Köhler 照明法を適用している。此の時 には光源は集光レンズに一度結像する為に, その光源の 形が密集して小さい程照明の效率が高い。

以上述べた樣な諸条件を十分満足してくれるものに小 型映写電球がある。

之を光源として使えば良い訳である。

\section{1 小型映写電球を光源亡する場合}

私共はスライド幻灯機（Master lux）よりレンズと防 熱フイルター（之は青緑色のソリッドガラスフイルター であつて，之を使用すると光源の色温度は約 $4,000^{\circ} \mathrm{K}$ となるが，勿論天然色䫓微鏡写真撮影の時は色温度補正 フイルターを適応してフイルムのもつ適正色温度に合わ せる事に依り，その使用も可能である。此の場合は一応取 り外す事にした）を外し，集光レンズ（コレクター）は その鰮の位置に据えて使用している。映写用電球 (Fuji 印）は $100 \mathrm{~V} ， 500 \mathrm{~W}$ 用いている。斯 うすれば光窒を 作る手数もはぶけるし, 光源ランプと集光レンズ（コレ クター）との光朝合せは既にメーカーの手許で調整され ているのでその方の懸念も注ぶけて好都合である。

そこで此の椂な光源装置を設けた時の注意を $2 〜 3$ あ げておきたい。

先に記した様にスライド幻灯機に附属していた着色のソ リッドガラスフイルターを除外してあるので之に代る天
然色写真に適する防熱フイルターを装備する事を忘机て はならない。

光量の高いダングステン電球を使用する Köhler 照明 法の防熱フイルターとして，種々の製品が発売さ机てい る。例えば厚さ $55 \mathrm{~mm}$, 径 $80 \mathrm{~mm}$ の熱線吸収用水槽（C. Zeiss）や干渉フイルター文は断熱フイルター（日本光 学,オリンパス) 等があるが,私共注染色バットに蒸溜水 を充たして使つているが之で一応間に合つている。一般 の検鏡に無㙨溶液 $\left(\mathrm{CuSO}_{4}\right.$ 等 $)$ を容れた小型フラスコを使 う事があるが天然色写真の昜合には両者共に良くない。

次に是非ボルトメーターのついたスライダックを備え る必要があると言う事である。

之は電圧を何時も一定にしておく為であつて, 斯うす る事に依つて光源の色温度も亦一定に保たれるからであ る。（電圧 $\pm 10 \mathrm{~V}$ の変動に依つて色温度は $\pm 100^{\circ} \mathrm{K}$ 上 下する)。

私共は常時 $100 \mathrm{~V}$ に光源電匠を保つ様汅している。此 の時の色温度をスイス, Weka 社製のルビコフ (Rebikof）色温度計で測定してみると大約 $2,500^{\circ} \mathrm{K}$ で使用すべ き補正フイルターは人工光用カラーフイルムを使う場合 にはワルツB 6を，寔光用カラーフイルムを使用する場 合はワルッB 4+B11を使えば良い。色温度補正フイル ターについては更に後述する。

補正フイルターはカラーバランスの事を考えて数種揃 えておいた方が良い。

此の種ダングステン電球は相当高度の光量が得られる ので，若し明る過ぎる時は粗面にワゼリンを整つたスリ ガラスを $1 〜 2$ 枚コレクターとコンデンサーとの光路の 中間に打く。

置く位置に依つて明るさが調節出来る。又直接検鏡す る必要のある時㟊色ガラスを適当の大きさに切り，之 を光路に打け浪い。併し視野の決定は予的一般検鏡の 際ペンでデッキグラスにマークを付けておき，写真撮影 の場合にはすぐ予定の視野が出せる様にしておかねばな らない。

私共は敍上のスリガラスや乳色ガラスを插入する為に ガラスが数枚仕組める様な衝立を自作して，重宝してい る。(第 2 図参照)。

\section{2 光軸合わせ}

先ず照明に必要な主な条件を挙げてみると，

a 標本の中に光源, 又潗光レンズ (コレクター) の如き光源に準ずるもの (Köhler 照明法の際の二次光 源）の像が出来ていること。

b 対物レンズの鏡口角と等しいか又法その $9 / 10$ 相当 
のコンデンサー（場合に依つては反射鏡）の鏡口角があ ること。

c 視野が平均して強く照明されていること等であろ う。

此等の条件を充たす為に光軸合わせと言う操作をする 必要がある。照明系の光軸合わせを行う前に顕微鏡の反 射鏡が正確に指定の位置に在るかどうかを確認してお く。尤も名の通つたメーカーの顕微鏡ならば,メーカー の手許で此の調整は既に済んでいるので更めて問題にす る必要はない。併し念の為此の調整法を簡単に紹介して おこう。

先ず対物レンズと接眼レンズとをはづし，サブステー ジの絞りを極小まで絞る。顕微鏡を垂直に保ち，平面側 を上向にして反射鏡を水平にし，反射鏡と同形同大の白 紙を切り，直径を直交する様に二本書き込んで円の中心 が分る様にする。此の白紙を反射鏡に良く合わせた上で 白紙の端をセロテープで貼りつけ，更に対物レンズ受ネ ジ部と接眼レンズの受口部に，中心にピンホールを開け た紙を貼る。そこで接眼レンズ受口部に置いたピンホー ルに眼をつけると反射鏡上の白紙が見える。白紙の円の 中心がこのピンホールに納つていれば良い訳である。

次に白紙のついた反射鏡を水平位置から垂直に立て る。光源の集光レンズ（コレクター）と鏡基の反射鏡と の距㒕はコレクターの焦点距離又便宜的に光源電球と コレクターとの距離の約 8 倍の距離をおく。即ち私共の 場合は約 $45 \mathrm{~cm}$ 。勿論此の距離は絶対的なものではなく 必要な事はむしろ光源のフイラメントより発する光束の 中心が Köhler 照明に使わ秃る集光レンズ (コレクター) の中心を通ると言う事であろう。併し之もスライド幻灯 機を使う場合はメーカーの手許で調整されているので光 源とコレクターとの光軸合わせ及び両者間の距離は敢え て問題にする必要はない。

唯反射鏡の白紙が最も明るく照射される様に幻灯機の 方向を決める。

次いで反射鏡上の白紙を除き, 光源からの光が顕微鏡 に入る様反射鏡を傾ける。此の時コンデンサーの上面で フイラメントが結像する様であれば良い（コンデンサー の上面に白紙を当てると結像が見易い)。

此の様に諸要素の距離と位置が決まつたら鏡基の足と 幻灯機の足を机上に縁取りしておくと次回の使用時に便 利である。

勿論此の場合固定されたカメラ䋰架台を使用するので あればカメラの方へ顕微鏡を取付ける要領で顕微鏡の位 置を決めなくてはならない。そしてカメラのピントグラ
ス面の中央に光軸が導入される様反射鏡の方向を決め る。

次いで対物レンズ及び接眼レンズを取り付け，標本を 載物台に入れ，焦点を合わせれば照明は正確になされて いる筈であるから，均一な照明が視野一杯に充ちている のが伺われる。

顕微鏡の対物レンズとコンデンサーの共軸調整につい ては，コンデンサー絞りの処で言及した。此の調節はメ 一カーの手許で既に行われており，先ず心配はない。も つとも Leitz-Dialuxにある様に左右に取り付けたネジに よる調節機構があれば有利である。

之で一応光軸合わせを完了した事になるがカメラのピ ントグラス面への光軸導入についての説明を少しく追加 してみたい。

先ずカメラ懸架台双は三脚に取り付けたカメラの真下 に顕铠鏡を据え，コンデンサー絞りを最小にし，コンデ ソサーを最上位にしておく。対物レンズは低倍率のもの をつけ, 光源を点灯してカメラのピントグラスを観察し つつ粗動ネジを备して鏡筒を少しずつ下げて行くと，ピ ントグラスの中央にコンデンサー絞りの実像が見える筈 である（若し中央になければ真中に収まる様反射鏡の方 向を少し調整してみる)。そして更に鏡筒を下げて行く と今度はピントグラスの中央に光源の実像（フイラメン トの像）が倒立像として見えて来る。此の様にコンデン サー絞りや光源の像がピントグラスに映るのは之等の実 体がコンデンサーで実像に投映されて，それが顕微鏡の 光学レンズ系に依つてカメラのピントグラスに投影され る為である。

合低倍率撮影を行うには，先ずュンデンサーの位置を 出来るだけ下げて見る。それでも大きい照野が得られな い時はコンデンサーの上部レンズを外してみる。それで も末だ不十分ならばコンデンサーを外して凹面乃至平面 反射鏡を利用してみる。大型標本の全野を出したい様な 場合には一般写真撮影で行う様に顕微鏡を用いず，中間 リングとカメラレンズを組合わせて接写を行う事もあり 得る。劣之は天然色顕微鏡写真とは全く関係ないが標本 そのもの（オブエクトグラス）を 2 时角に切り，スライ ドとして使用する方法も一部では行われている。

\section{3 電気露出計}

顕豃鏡用電気露出計として役立つ為には，それが余程 高感度である事が必要となつて来る。一般カメラ撮影用 のものは最低 $2 \sim 3$ ルックス位にしか感じないが, 顕微 鏡写真撮影の場合だと 0.1〜0.01 ルックスにも感じ得る 精度が要求されて来る。 
之には光電池を用い，更に高感度を保つ為に 2 次電位 増倍管を附し，㭘流計に依つて読みをとる様になつてい そのが望ましい。此の型だと光の入射光を $0.5 〜 1.0 \mathrm{~mm}$ 位にしてあえ為例えば標本中の最暗部も限局して測定が 忺来る訳である。

又使用一る色温度䋠非フイルターとのも0０）露光係数

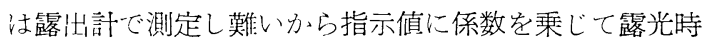
間を決める様にする（第 1 表参照）。

併し，私共は色温度補正 フイルターを照明係に含め て，（実際にはコンデンサー絞りの真下にフィルターの 載る様なブリキの台を取り付け，弦にフイルター一を置い た）カメラのビントグラス面の照度を計り, 露光時間を 決定しているので露光係数は特別考慮に入れてない。

高性能の露出計を備える様にすべきではあるが，どう も私共の経験では全面的な信頼をおき得ると言つたもの は現在ない様である。

従つて此の種の露出計があつても標本を変えるとか倍 率を变えると言う場合にはやはり経験的事項も参考にい れなくてはならないので撮影每の各条件を克明に記録 し，整理しておく様心掛けるべきである。

露出計には適正照度曲線や計算盤が附属されていて便 利であるが始めにパンクロフイルム（ミニコッピーが良 い）を使い，染色法の違つた標本や種々の倍率で一度試 し撮りを行い，指定通りの現像の結果を検討する事によ つて露出計の性能及び適正露出度を確めておくが良い。

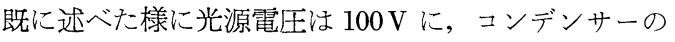
位置を決め, 更にコンデンサー絞りは対物レンズのもつ N.A.の約 $9 / 10$ に夫々決められているので, 露光量の調 節はコレクターとコンデンサー間の光路にスリガラスを 置くこと及びシャツタースピード（之も $1 / 25 〜 1$ 秒間の 範囲で）等に依つて為される事になる。

\section{V. 写真撮影装置と写真技術}

現在の段階では $35 \mathrm{~mm}$ サイズのカラーフイルムが最も 実用的である。又小型カメラによる顕微鏡写真装置が種 々考按されて，優れた製品が発売されている。Leitzの ライカシステムはその附属品の豊富な余り, 却つて使用 者にとつては煩雑ささえ感ずる位である。代表的国産品 としては日本光学から F M A 型（二コン用），F M B 型 (ライカ用), キヤノンカメラからはデータープロジエ クターのついた装置, オリンパスから小型顕微鏡写真装 置 P M-6が夫々発売されているが，之等は所謂鏡筒用 写真装置 (eye piece camera) の為のものであつて, フ フインダー接眼レンズヌはピント枠への分岐光路にプリ
ズムが仕組んであり，此の型の多くは半透過式であり， ピントグラス面の照度を下げるばかりでなく，プリズム に依る色相の変化が伴うので，黑白写真の場合にはむし ろ効果的作用をもつが，カラー用としては良くない。そ の他ミラー式のものが松島写真用品からミラックスの名 で発売されているが，マイクロナダプターと組合せて⿺尢丶 はり eye piece camera の形式をとる揧になる。

此の様な eye piece comera 様式は, カメラの重量か 顕微鏡に負荷され，鏡筒が沈下する場合がない訳ではな く(Leitz-Dialux や日本光学 $\mathrm{S}$ 型の如く, 鏡筒が-すうか り鏡基に固定されていて，ステージの上下に依つてピン トを調節んる型のものは此の心配はない)，のみならず 金属的な密接（アダプターの使用）によつてシヤッター の振動が顕微鏡に伝畨与る䀣念も出て来るので，必ずし も理想的なものばかりとは限らない。

\section{1. 顕微鏡写真撮影装置}

そこで私共の現在行つている装置を第 2 図に示したの で，之を御覽になれば大体理解して頂けると思う。特に 説明を加えると言つたものはないが, $2 \sim 3$ 述べると,複 写台のカメラ眯架台には中間リングをつける。この中間 リングは長さの異つた数種があり，夫々その長さが $\mathrm{mm}$ 単位の数字:で刻ま机てあり，之を適宜組合わせて使えば 良い。又中間リングと接眼レンズとは遮光接続具を使う と便利であるが，入手出来ない場合は遮光用暗幕を適当 な衰さ（余裕を持たせておく）に切り，筒状に縫い合わ せ，闭端がよく䋨まる様にゴムを入れたものを当てがっ ても良い。

前述した綜合倍率：Mが必要となる時の事を考えて撮 影前にフイルム面と接眼レンズの射出瞳孔位との距離 : 1 を実測しておくと良い。中閒リングの代りに伸縮自在 な而も目盛のついた蛇腹のフォーカベルを用いるとトリ ミングも亦自由に出来て良いが，此の時はミラーボック 大を併用する等却つて装置が複雑になつてしまう。

\section{2. 天然色感光材料亡色温度補正フイルター}

今日一般に供給されている天然色写真感光材料は，昼 光用と人工光用との 2 程類があり，大体に於いて前者は $5,500^{\circ} \mathrm{K}$ (Kelvin degree) 程度の)色温度に, 又人工光用 のものは $3,200^{\circ} \mathrm{K}$ 程度の色温度に適合与る様に作られ ている。例外的に Ektachrome Type $\mathrm{F}\left(3,800^{\circ} \mathrm{K}\right.$ 夙光 電球用）や Telcolor negative（昼光，人工両光用）等 がある。

現在知ら札ている然色感光材料はフイルム名から言

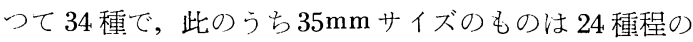
フイルム名が挙げられる。 
顕微鏡写真撮影装 置

第 2 悯

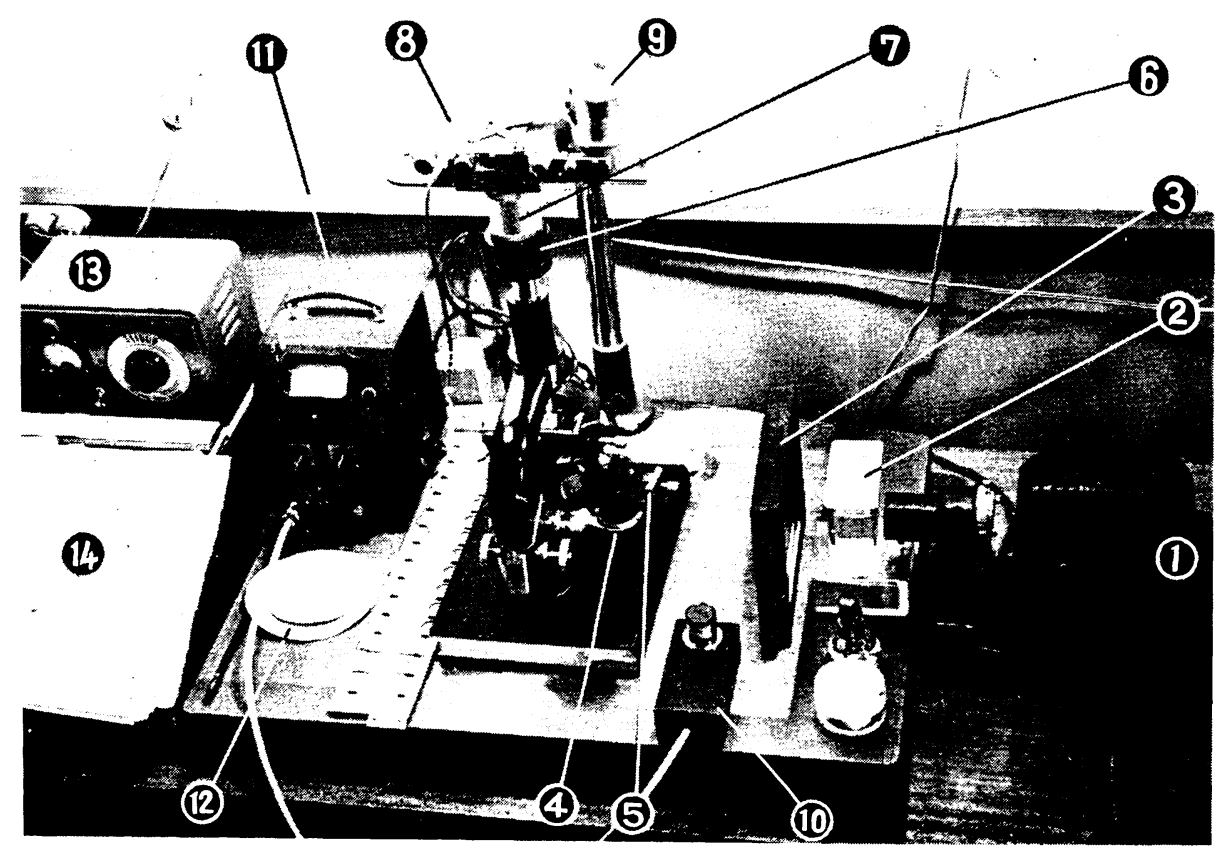

複写台を利用した顕微鏡写真撮影装置の例

(1) 光源（マスター幻灯機，500W，同機から防熱フィルターと焦点用レンゼを除く。但し 2 枚組 コレクターはその儘使用)

(2) 防熱用水槽（蒸溜水を充した染色バット，理想的ではないが一灾使える）

(3) 手製スリガラス用衝立（スリガラスが 4 枚組める様にしてある。光量の調節に適時使用）

(4) 手製フイルター受及びカラー用フイルター（ワルッ）

(5) サブステージにあるコンデンサー絞り（コンデンサーの高位を知る為，コンデンサーの上下す るレールの測面に手製の尺度をセロテープで貼布したが，写真には見えてない）

(6) 接続具（上下のセパレイッから成る）

(7) 接写用中間リング

(8) $35 \mathrm{~mm}$ カメラ（スライデイング様式のカメラ架台に取付けたとこる）

(9) ピントルーペ(ピントグラスの上に置いたところ)

(10) 受光器（第 2 次電子増倍管, 之をピントグラスの上に当てる)

(11) 増巾器 $(10,11$ : 下代田光学顕微鏡用露出計)

(12) 露や值計算般

(13) 電圧調整器

(14) 記敛簿（之は是非用意すべきである） 
型式から言うと内式反転が 11 種で一番多く，次が色 ネガで 7 種（国産 1 種: オリエンタルカラー，ネガテイ ブフイルム), 外式反転が 5 種（国産 2 種: フジカラー 及びさくら天然色フイルム)，単一板規則モザイクスク リーンが 1 種となつている。

天然色顕微鏡写真を撮る場合には人工光用が望まし く，自家現像の可能な内式反転フイルムが 便利である 為, 病理学方面では Ansco color が専ら愛用されてい る。

国産のものは昼光用，外式反転フイルムがあるだけな ので，之を使用する場合には殊更に光源の色温度が使用 されるカラーフイルム（が調整されているところ）の色 温度に適合する様鋭意補正しないと，正しい色再現が望 をれない。（吻論此の事は人工光用フイルムを使用する 場合にも適用される)。そこで更めて色温度補正と言う 事に就いてつけ加えておきたい。

光源の色温度の変化が天然色写真の色に, はつきり認 め得る变化を与える程度は, その色温度の高低に依つて 違い, 色温度 $5,500^{\circ} \mathrm{K}$ 程度の場合には, 大約 $300^{\circ} \mathrm{K}$ 程度以上の色温度の変動があると, 色の変化が認められ て来る。従つて $5,500^{\circ} \mathrm{K}$ に適合する様に調整された昼 光用のものでは, 色温度が $5,200 \sim 5,800^{\circ} \mathrm{K}$ 範囲内 の 変動ならば問題はないが, 之以上の変動があると色温度 補正フイルターを用いねばならない。

色温度 $3,200^{\circ} \mathrm{K}$ に適合する様に調整されている人工 光用の場合には， $100^{\circ} \mathrm{K}$ 以上の色温度の变動があれば, 色の变化が認められるので, 光源の色温度が 3,100 $3,300^{\circ} \mathrm{K}$ の範囲を越える場合には，色温度補正 フイル ターを用いるばならない。

此の様に色再現に影響を与える色温度変動の美が色温 度の高い場合には $300^{\circ} \mathrm{K}$, 低い場合には $100^{\circ} \mathrm{K}$ と異 つているのは如何にも不便である。そこでミレッドと言 う単位を適用してみよう。之は色温度の逆数に $10^{6}$ を乗 じたもので Micro reciprocal degree の略; Mired で, 記号Mで表わされる。

例光ば色温度 $5,500^{\circ} \mathrm{K}$ は $182 \mathrm{M}$ であつて, $5,200^{\circ} \mathrm{K}$ (約 $192 \mathrm{M}) \sim 5,800^{\circ} \mathrm{K}$ (約 $172 \mathrm{~K}$ ）の範囲, 即ち \pm 10 M以内の変動では, 色温度補正フイルターの必要はな

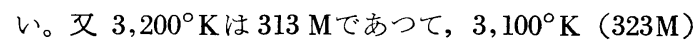
$\sim 3,300^{\circ} \mathrm{K}$ (303M) の範囲内, 即ち $\pm 10 \mathrm{M}$ 以内の变動 では, 色温度補正フイルターの必要はない。ミレッド単 位によると色温度変動の許容範囲が共に \pm 10 で表わさ れ得る。

従つて各色温度補正フイルターに依つて变動するミレ
ッドが分れば色温度の補正は簡単に行われ得る。

例えば実際の 光源が $400 \mathrm{M}$ (色温度約 $2,500^{\circ} \mathrm{K}$ ) の 時に，182M（色温度 $5,500^{\circ} \mathrm{K}$ ) に適合するカラーフイ ルム, 即ち昼光用を使用する場合には, ミレッドの変化 が 218M のブリエー系の色温度補正フイルター，例㫕 ばワルッ B $11+$ B 4 を使光ば良い。又同じ光源で $313 \mathrm{M}$ （色温度 $3,200^{\circ} \mathrm{K}$ ）の人工光用カラーフイルムを使用 する時は，87Mだけ変化するブリユー系の色温度補正フ イルター，例えばワルツB6を使えば良い事になる（第 1 表参照)。之等は光源の色温度の低い場合に，色温度 の高い感光材料に適合させる為にブリユー系の色温度補 正フイルターを用いたが，逆に光源の色温度の高い場合 に, 色温度の低い感光材料に適合させる為にはアンバー 系の色温度補正フイルターを用いる。

日常の撮影に之等の補正フイルターを使う場合は必ず 露光倍率だけ乗じた露光時間を与えなければならない。

色温度補正フイルターの種類とそのフイルターによつ て変化するミレッドの近似值及び大略の露光増加倍率等 を第 1 表に示した（が妶に述べる私共の方法では此の露 光倍率を考虑に入れてない旨は前述した)。

\section{3. 露 光 時 間}

斯る照明, 斯る顕微鏡写真撮影装置を使うとして, 此 の上実施者にとつての切実な問題が残されているとする ならば，それはやはり露光時間の決定と言う事であろ う。

次に手つ取り早く私共のノートから任意にデータの一 部を拾い上げて，之に就いて若干の考察を加えてみる事 にしたい（第 2 表参照)。

先に露光時間は $1 / 25 〜 1$ 秒間にしたい旨を述べたが， A S A 1.5 と言う可成感光度の低いアンスコカラーフイ ルム，人工光用を使つた為 4 秒の長時間露光を与えざる を得なかつた。その為には時間の適正を期する為, ス卜 ツプオッチを使用した。之を補う為に光源はもつと出力 の強いものを希つたが私共の使用している幻灯機は 100 $\mathrm{V}, 500$ 7 $50 \mathrm{~W}$ と指定されている虑, 此の点限度があつ た。併し現在アンスコカラー，人工光用にはＡＳＡ 32 と言うカラーフイルムとして可成高感度のものが発売さ れているので，光源電圧を例えば $85 \mathrm{~V}$ に落して，光源 電球の寿命を温存し乍ら，而も $1 / 25 \sim 1$ 秒のシヤッター スピードを十分利用出来る筈である。

次にミレッド単位に依る計算の結果選んだ色温度補正 フイルターを昼光用フイルムには B 4 + B 11 を, 人工光 用フイルムにはB 6 を夫々使用した場合, 出来上りは自 然光で観察すると稍々青味を带びる傾向を認める。併し 
第 2 表

\begin{tabular}{|c|c|c|c|c|c|c|c|}
\hline $\begin{array}{l}\text { レンズ (ライツ) } \\
\text { 対物 } \\
\text { レンズ、按 眼 }\end{array}$ & $\begin{array}{r}\text { コンデンサー } \\
\text { 絞り }\end{array}$ & $\begin{array}{r}\text { コンデンサー } \\
\text { 高位 }\end{array}$ & $\begin{array}{l}\text { 接眼レンズ上の射 } \\
\text { 出瞳孔とフイルム } \\
\text { 面との距離: } 1\end{array}$ & 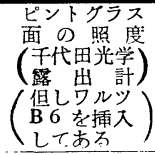 & $\begin{array}{l}\text { A S A 25(ミニュ } \\
\text { ツピー) の場合の } \\
\text { 計算盤の簬光特間 }\end{array}$ & 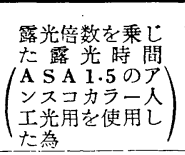 & $\begin{array}{l}\text { 実際に行つた露 } \\
\text { 出時間及び方法 }\end{array}$ \\
\hline $\begin{array}{c}3.5 \times 10 \\
\text { アクロ } \\
\text { マート プラン } \\
\end{array}$ & 5 & コンデンサー & $127^{\mathrm{mm}}$ & $110 \mu \mathrm{A}$ & $\begin{array}{c}1 \\
40\end{array} \frac{1}{15}$ & $-1{ }^{1}-\times \frac{25}{1.5}=0.7$ & 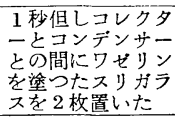 \\
\hline $\begin{array}{c}10 \times 10 \\
\text { アクロ } \\
\text { マート シ゚ソフ }\end{array}$ & 6 & 2 & 130 & $70 "$ & $\frac{\frac{1}{25} \sim-\frac{1}{15} \text { (仮 }}{\text { 設) の中間 }}$ & $\frac{1}{15} \times \frac{2.5}{1.5}=1.1$ & 1 秒 \\
\hline $\begin{array}{c}42 \times 10 \\
\text { フルオ } \\
\text { リーリプ } \\
\end{array}$ & 15 & 1 & $129^{\prime \prime}$ & $15 "$ & $\frac{1}{5} \sim 1-\frac{1}{4}$ & $\frac{1}{4} \times \frac{2.5}{1.5}=4.2$ & $\begin{array}{l}\text { 4秒 } \\
\text { ス爰 } \\
\text { を使用 }\end{array}$ \\
\hline 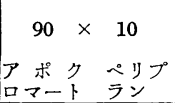 & 21 & 0.5 & 130 & $15 "$ & " & " & $\begin{array}{l}4 \text { 秒 } \\
\text { スソ゚ォツチ } \\
\text { を使用 }\end{array}$ \\
\hline
\end{tabular}

私共がスライドを使う場合は殆えど幻灯機にかける。此 の幻灯機から出る光の色温度は前述した如く大約 4,000 ○Kであつて多少共青味を带びるスライドもスクリーン では中和される様に思われる。

私共も経験的に段階の異つた補正フイルターを用いて 結果を判定してみたが，アザン，トリクローム及びチー ル，ネルゼン染色等ではB 6, B 4+B 11 を適用した方 が良く, へマトキシリン，エオジン染色の場合，やはり アクロマート対物レンズではエオジンの色が再現してい ない恨みがあり，此の様な場合にはむしろ，人工光用フ イルムにはB 4, 昼光用フイルムに対してはB 9 程度が 良いと言う様な結果を得た。併し露出時間を適正に決め るという事の方が重要である様に思われる。

\section{4 内式カラーフイルムの現像処理}

私共は現在冝光用, 外式型式の国産カラーフイルムか ら人工光用且つ内式型式のアンスコカラーフイルムに切 換えつつあるが，天然色顕铛鏡写真用のフイルムとして は,やはり此の型式のものが推奖されるのは言うまでも ない。

此の程度の現像処理は暗室設備のある様な処なら至極 簡単に出来る。

私共はアンスコ会社から発表されている処方に依つて 試薬を調合し，多少実施法を変えて行つている。

\section{1. 試薬の調製}

a 第 1 現像液 (アンスコ No. 502)

$\begin{array}{lr}\text { 水 }(60-70 \mathrm{~F}) & 750 \mathrm{cc} \\ \text { メトール } & 3 \mathrm{gm} \\ \text { 無水亜硫酸ソータ } & 50 \mathrm{gm} \\ \text { ハイドロキノン } & 6 \mathrm{gm} \\ \text { 無水炭酸ソータ } & 40 \mathrm{gm}\end{array}$

ロタンカリ

$2.4 \mathrm{gm}$

臭化カリ

$2 \mathrm{gm}$

水を加元て

$1,000 \mathrm{cc}$

b 停止液（アンスコ No. 858)

\begin{tabular}{lr} 
水 $(60-70 \mathrm{~F})$ & $750 \mathrm{cc}$ \\
水醋酸 & $10 \mathrm{cc}$ \\
酷酸ソータ & $20 \mathrm{gm}$ \\
水を加えて & $1,000 \mathrm{cc}$ \\
\hline
\end{tabular}

c 発色現像液

水 $750 \mathrm{cc}$

チェチルパラフエニレンチアミン塩酸堤 $4 \mathrm{gm}$

無水覀硫酸ソー夕 $1.2 \mathrm{gm}$

無水炭酸ソータ $67.5 \mathrm{gm}$

臭化カリ $1 \mathrm{gm}$

水を加えて $1,000 \mathrm{cc}$

d 清净液 (アンスコ No. 854)

重亜硫酸ソータ $10 \mathrm{gm}$

醋䣹ソータ $20 \mathrm{gm}$

水を加えて $\quad 1,000 \mathrm{cc}$

e 硬化液 (アンスコ No. 901)

水 $750 \mathrm{cc}$

クローム明管 $30 \mathrm{gm}$

f 漂白液 (アンスコ No. 800)

水 $750 \mathrm{cc}$

赤血堤 $60 \mathrm{gm}$

·臭化カリ $15 \mathrm{gm}$

第2 燐酸ソー夕 $13 \mathrm{gm}$

（指定がないので私共は無水を使用）

重硫酸ソー夕 $0.6 \mathrm{gm}$

（指定がないので1/水塩を使用）

水を加えて $\quad 1,000 \mathrm{cc}$

$\mathrm{g}$ 定着液（所謂単八1ポ）

水 $750 \mathrm{cc}$

チオ硫酸ソータ（ハイポ） $200 \mathrm{gm}$

水を加えて $\quad 1,000 \mathrm{cc}$ 
之等溶液注暗所に貯える。

2 . 実施法（但し, 液温は $18^{\circ} \mathrm{C}$, タンク現像）

私共は 7 個のほうろう引き砂桾入れを用意して，夫々 の試薬を容れ，良く液を切り乍らタンク現像に使うリー ルを順次進める様にしている。液の混入が少くてすむ。

\section{1 ）第 1 現像液 20 分}

（始めの 5 分間は静かに攪拌する。此の際ベルト式の 場合にには気泡が残らぬ様タンクの壁で 4 〜 度リール を打ちつけると良い。後は 1 分毎に 5 秒位リールを廻転 させる程度で良い。余り強く振盪させると膜面をはがす から注意する。)

\section{2）停止液 3 分}

3 ) 流水で洗う 1 分 以上暗黒で行う。

4) 第 2 露光： 3 分 $(100 \mathrm{~V}, 500 \mathrm{~W}$ のフラッ゙ランプ から約 $1 \mathrm{~m}$ 離れて 1.5 分ずつフイルムの両面を露光す る。）此の場合フイルムをリールから外して行い，第 2 露光が終つたら再びリールに巻きつける。

以下，電灯下で操作して良い。
5 ) 発色現像液
20 分

第 1 現像の時の要領で。

6 ）清浄液

3 分
7) 硬化液
5 分
8）流水で洗う
5 分
9）漂白液
10分
10）流水で洗う
3 分
11）定着液
5 分
12）流水で洗う
10 分

之はフイルムをリールから外して行う。

13）ドライウエル（富士）又はコニダックス（小西六 等に数秒間浸し, 後乾懆。

\section{VI. あとがき}

カラーフイルムの進歩は著しく, 従つて現像処理が 雑で, 撮影者が自家現像出来ない外式反転フイルムは: 第に自家現像の可能な内式フイルムに依つてとつて代 れ様としている。此の点国産のある社のカラーは稍々 ち䐅れの感があるが, 新しい内式反転フイルム, 内式 ラーネガフイルム，内式カラー印画紙等が製造発売さ: る日の近い事を期待せざるを得ない。

以上私共の試みている天然色顕微鏡写真の一般的な: 技と言つたものを述べてみた。何等かのご参考になれい 幸歁であり, 又ご批判を頂けれ望外の喜びでもある。

第 1 表

\begin{tabular}{|c|c|c|c|c|c|c|}
\hline \multicolumn{3}{|c|}{ アンパー系色温度補正フイルター } & \multicolumn{4}{|c|}{ フリユー系色温度補正フイルター } \\
\hline フイルター番号 & $\begin{array}{l}\text { フィルターに依り变化 } \\
\text { 寸るミレット近似值 }\end{array}$ & 露 光 倍率 & フイルター & -番号 & $\begin{array}{l}\text { フィルターに依り変化 } \\
\text { するミレッド近值 }\end{array}$ & 露 光 倍 率 \\
\hline ワルツ A 0 & 10 & 1.1 & ワルツ B & В 0 & 8 & 1.2 \\
\hline A 1 & 19 & 1.1 & & B 1 & 18 & 1.4 \\
\hline A 2 & 35 & 1.2 & & B 2 & 33 & 1.6 \\
\hline A 3 & 50 & 1.5 & & B 3 & 46 & 1.9 \\
\hline A 4 & 63 & 1.6 & & B 4 & 60 & $2 \cdot 0$ \\
\hline A 5 & 75 & 1.7 & & B 5 & 71 & $2 \cdot 3$ \\
\hline A 6 & 86 & 1.8 & & B 6 & 83 & 2.4 \\
\hline A 7 & 100 & 1.9 & & B 7 & 96 & 2.7 \\
\hline A 8 & 113 & $2 \cdot 1$ & & В 8 & 111 & 2.9 \\
\hline A 9 & 128 & $2 \cdot 2$ & & B 9 & 127 & $3 \cdot 1$ \\
\hline A 10 & 146 & 2.5 & & B 10 & 136 & 3.2 \\
\hline A 11 & 159 & $2 \cdot 7$ & & B 11 & 156 & $3 \cdot 9$ \\
\hline A 12 & 180 & $2 \cdot 8$ & & B I2 & 178 & $4 \cdot 3$ \\
\hline フシ C C A 10 & 57 & 1.2 & フシ C C F & B 10 & 44 & 1.4 \\
\hline C C A 20 & 63 & 1.5 & C C F & B 20 & 68 & 2.0 \\
\hline C C A 50 & 131 & 2.0 & C C I & B 35 & 131 & 2.7 \\
\hline
\end{tabular}




\section{主要参考文献}

1. 林 一男：顕微鏡写真の実技, アミコ出版社（昭 和 29 年 5 月)

2. 林 一男: 天然色顕微鏡写真, すぐに役立つ写真 技術,化学の領域増刊16号,頁100-110, 南江堂 (昭和 29 年 8 月)

3. 田島又一: 光学顕微鏡写真, すぐに役立つ写真技 術, 化学の領域増刊16号, 頁111-130, 南汇堂 (昭和 29 年 8 月)
4. 笹井 明: カラー写真, アサヒカメラ講座 5 , 朝 日新聞社 (昭和 30 年 8 月)

5. 宮本五郎・奥沢和夫：天然色写真，写真技術講座 5 , 共立出版 $K \cdot K$. (昭和 31 年 3 月)

6. 大場栄一：収差, アサヒカメラ, 41（11）：132 （昭和31年11月）

7. SHILABER, C. P.: Photomicrography in theory and practice, John Wiley \& Sons, Inc. (1949) 